\title{
Evaluation of the Prevalence of HER-2 Expression and Its Relationship with Prognostic Parameters in Colorectal Carcinoma
}

\author{
Kolorektal Karsinomlarda HER-2 Ekspresyonu Sıklığı ve Prognostik Parametreler ile \\ ilişkisinin Değerlendirilmesi
}

\author{
Cansu Benli Ișık1, (10 Saime Gül Barut22
}

1 University of Health Sciences Turkey, Samsun Training and Research Hospital, Clinic of Medical Pathology, Samsun, Turkey

ZUniversity of Health Sciences Turkey, Haseki Training and Research Hospital, Clinic of Medical Pathology, Istanbul, Turkey

\begin{abstract}
Introduction: Colorectal carcinoma (CRC) is one of the most important causes of cancer-related deaths, and its incidence has been increasing in recent years. Considering the high mortality rates, new therapeutic targets are needed to improve survival in advanced disease. HER-2 is a member of the Epidermal Growth Factor Receptor family. Overexpression of HER-2 is related to malignant transformation, apoptosis and increased proliferation. In this study, the frequency of HER-2 expression in CRC and its relationship with prognostic parameters were examined.
\end{abstract}

Methods: A total of 123 colorectal resection cases diagnosed as CRC in 2015-2016 in the Pathology Department of Haseki Research and Training Hospital were included in the study. Clinicopathological prognostic parameters were evaluated. Immunohistochemical staining of HER-2 was performed on slides obtained from selected paraffin blocks. The results of staining were scored as $0,1+, 2+$ or $3+$. For statistical analysis, HER-2 scores of 0 and $1+$ were considered as negative, $(2+)$ scores as equivocal and (3+) scores as positive.

Results: $3+, 2+$ and $1+$ immunoreactivity (strong, medium and weak intensity of membrane staining, respectively) was detected in $13 \%, 21 \%$ and $16 \%$ of cases, respectively. When we compared the results of HER-2 status with the clinicopathological parameters, we found a correlation between HER-2 and distant metastasis. The distant metastasis rate was higher in HER-2-positive patients than in equivocal and negative patients. There was no significant relationship between HER-2 expression and other clinicopathological parameters we evaluated.

Conclusion: Considering these HER-2 expression levels which not scarce, therapies targeting the HER-2 receptor can be a promising part of treatment regimes, although they are not the main treatment option in CRC.

Keywords: Colorectal carcinoma, HER-2, C-erbB-2, prognostic parameters

\section{öZ}

Amaç: Kolorektal karsinom (KRK) kansere bağlı ölümlerin en önemli sebepleri arasında yer alır. Görülme sıklığı son yıllarda artış göstermektedir. Yüksek ölüm oranları gözönüne alındığında, ileri hastalıkta sağkalımı artırmak için yeni terapötik hedefler gerekmektedir. HER-2, epidermal büyüme faktör reseptör ailesinin bir üyesidir. Overekspresyonu malign transformasyon, apopitoz azalması, artmış proliferasyonla ilișkilidir. Bu çalıșmada KRK'lerde HER-2 ekspresyon sıklı̆ı̆ ve prognostik parametrelerle ilişkisi araştıııldı.

Yöntemler: Haseki Eğitim ve Araştırma Hastanesi Patoloji Bölümü'nde 2015-2016 yıllarında KRK tanısı konulan 123 kolorektal rezeksiyon olgusu çalışmaya dahil edildi. Klinikopatolojik prognostik parametreler değerlendirildi. Olguların seçilen parafin bloklarından elde edilen kesitlere HER-2 immünohistokimyasal boyası uygulandı. Boyanma sonuçları $0,1+, 2+$ veya $3+$ olarak skorlandı. istatistiksel çalışma için skor 0 ve $1+$ olanlar negatif, skor $2+$ olanlar şüpheli, $3+$ olanlar pozitif olarak kabul edildi.

Bulgular: Olgularımızın \%13'ünde 3+ (kuvvetli yoğunlukta membran boyanması), \%21'inde $2+$ (orta yoğunlukta membran boyanması), \%16'sında 1+ (zayıf yoğunlukta membran boyanması) immünoreaktivite saptandı. Değerlendirilen klinikopatolojik parametrelerden uzak metastaz ile HER-2 arasında korelasyon saptandı. HER-2 pozitif hastaların uzak metastaz oranı şüpheli ve negatif hastalara göre yüksekti. Diğer parametrelerle ilișki tespit edilmedi.

Sonuç: Bu az sayılmayacak HER-2 ekspresyon düzeyleri dikkate alındığında HER-2 reseptörünü hedefleyen tedaviler KRK tedavisinde ana tedavi seçeneği olmasalar da, tedavi rejimlerinde yer alarak umut verici olabilirler.

Anahtar Kelimeler: Kolorektal karsinom, HER-2, C-erbB-2, prognostic parameters

Cite this article as/Atıf: Benli Issı C, Barut SG. Evaluation of the Prevalence of HER-2 Expression and Its Relationship with Prognostic Parameters in Colorectal Carcinoma. İstanbul Med J 2020; 21(3): 207-12.

(C) Copyright 2020 by the University of Health Sciences Turkey, Istanbul Training and Research Hospital/Istanbul Medical Journal published by Galenos Publishing House

(C) Telif Hakkı 2020 Sağıı Bilimleri Üniversitesi Istanbul Ĕgitim ve Araştırma Hastanesi/Istanbul Tıp Dergisi, Galenos Yayınevi tarafından basılmıștır. 


\section{Introduction}

Colorectal carcinoma (CRC) is the third most common cancer worldwide, with an annual incidence of 1.84 million cases. Approximately 888,000 people die of CRC each year, placing it second among cancer-related causes of death (1).

Despite advances in early diagnosis and treatment, advanced-stage disease accounts for approximately 50\% of newly diagnosed CRC, and survival rates in advanced disease are still not at the desired level (2). The development of targeted therapies directed against a specific mutation, such as the Epidermal Growth Factor Receptor (EGFR) and tyrosine kinase, has improved treatment efficacy and clinical outcomes in advanced disease (2-5). The increased incidence and high mortality rates require new therapeutic targets to improve survival.

Human EGFR 2 (HER-2) is a proto-oncogene localised on chromosome 17q21. The EGFRs HER1, HER3 and HER4 are members of the tyrosine kinase receptor family (6-10). Their overexpression is strongly associated with increased proliferation, increased cellular survival and decreased apoptosis, leading to maintenance of the associated carcinoma and malignant transformation $(6,11)$.

HER-2 overexpression and gene amplification have been studied in CRC, and the prevalence of overexpression was found to be between 0 and $83 \%$ (8). Membranous expression (2.1\%-11\%) and cytoplasmic overexpression (47.4\%-68.5\%) were observed in different studies (12).

In this study, we aimed to determine the incidence of HER-2 expression in CRCs and its relationship with histopathologic tumour type, tumour grade, pathologic stage, lymph node metastasis, lymphovascular invasion and other clinicopathologic prognostic parameters.

\section{Methods}

\section{Case Selection and Clinicopathological Parameters}

Resected colon and rectum tissues diagnosed with carcinoma between 2015 and 2016 were screened in the Medical Pathology Department of Haseki Training and Research Hospital. A total of 127 cases were detected. The slides were obtained from the archive. Two cases were excluded because their slides could not be found. Three patients with neoadjuvant therapy showed almost complete regression and were excluded from the study because they did not contain sufficient tumour tissue for evaluation. The second primary tumour was detected in three resection materials. The same criteria were evaluated for these tumours, and they were considered as different cases in the statistical analysis.

All cases were evaluated in terms of tumour type, grade, depth of invasion, lymphovascular invasion, perineural invasion, tumour infiltrating lymphocytes, Crohn-like reaction, presence of medullary and mucinous component, presence of high grade area, tumour nodules, effect of the treatment and regional lymph node involvement. Tumour blocks suitable for immunohistochemistry were determined. HER-2 immunohistochemical staining was applied to the selected blocks. After staining, two patient's slides could not be evaluated due to the lack of tumour tissue, and they were excluded from the study. Thus, a total of 123 cases were included in the statistical study.
No consent was obtained from the patients. The study was approved by the ethics committee of Haseki Training and Research Hospital $(428 / 22.02 .2017)$

\section{Immunohistochemical Method}

Sections of 2.5 micron thickness were taken from the selected tumour blocks and transferred to positively charged slides. The sections were deparaffinised in the incubator for 1 hour. Sections taken from the incubator were stored at room temperature for 10 minutes and then stained with a Ventana Bench Mark ULTRA fully automated immunohistochemistry staining device employing the ultra-view universal DAB protocol using the HER-2/neu (4B5) rabbit monoclonal primary antibody. After the staining process, the sections were washed with water for 5-10 minutes. The slides were dried, passed through $96 \%$ alcohol and xylene and closed by hand.

\section{Scoring}

Immunohistochemistry preparations were evaluated by light microscopy. Results were scored on a scale of $0-3+$ as suggested by the manufacturer $(8,13)$.

0 : no staining or $<10 \%$ membrane staining

$1+$ : Pale membrane staining in more than $10 \%$ tumour cells, part of the membrane can be stained

$2+$ : Weak-medium full membrane staining in more than $10 \%$ of tumour cells

$3+$ : Strong full membrane staining in more than $10 \%$ of cells

For the statistical study, HER-2 scores of 0 and $1+$ were grouped as negative, $(2+)$ scores as equivocal and $(3+)$ scores as positive.

\section{Statistical Analysis}

SPSS 15.0 for Windows was used for statistical analysis. Descriptive statistics were as follows: number and percentage for categorical variables; mean, standard deviation, minimum and maximum for continuous variables. Since the continuous variables were normally distributed within groups, two independent group comparisons were made using one-way ANOVA. Chi-square analysis was used to compare rates in groups. The level of statistical significance was accepted as $\mathrm{p}<0.005$.

\section{Results}

Of the 123 cases included in the study, 78 were male and 45 were female. The mean age of the cases was 62.2, and the age range was between 29 and 95 years. Tumours were located in the left colon in 56 (45\%) cases, rectum in $33(27 \%)$ cases, right colon in 29 (24\%) cases and transverse colon in 5 (4\%) cases. Tumour diameters were in the range of $0.4-10 \mathrm{~cm}$, and the mean tumour diameter was $5.3 \mathrm{~cm}$.

The cases included in the study consisted of two different histological subtypes, classical and mucinous. A total of 113 (92\%) cases had classic adenocarcinoma and 10 (8\%) had the mucinous adenocarcinoma morphological type. Other histological variants were not found in our study. 
One hundred (82\%) patients had a low histologic grade, whereas 22 (18\%) patients were of the high grade. One patient was not graded after treatment.

As a result of HER-2 immunohistochemical staining, HER-2 staining was observed in 61 cases (50\%). Of these 61 cases, 19 (31\%) had poor, 26 (43\%) had moderate and $16(26 \%)$ had strong intense membranous staining (Figure 1).

When we compared the results of Her-2 status with the clinicopathological parameters, we found a significant relationship between HER-2 and distant metastasis. The distant metastasis rate of HER-2-positive patients was higher than that of equivocal and negative patients. There was no significant relationship between HER-2 and other clinicopathological parameters we evaluated $(p<0.05)$. Table 1 shows the distribution of some clinicopathological data (gender, age, tumour size, localisation, histological type, grade, lymphovascular invasion, perineural invasion, lymph node metastasis status) according to HER-2 expression.
We could not obtain distant metastasis information in $20 \%$ of our cases. The distribution of HER-2 expression according to pathological TNM stage was examined, and the findings are shown in Table 2. There was no correlation with tumour depth and lymph node metastasis. However,

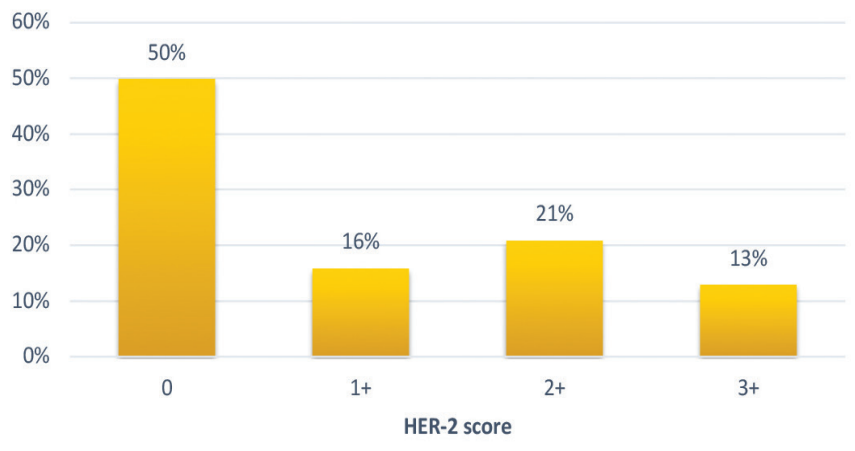

Figure 1. Distribution of cases according to HER-2 staining results

\section{Table 1. Distribution of some clinicopathological parameters according to HER-2 expression}

HER-2

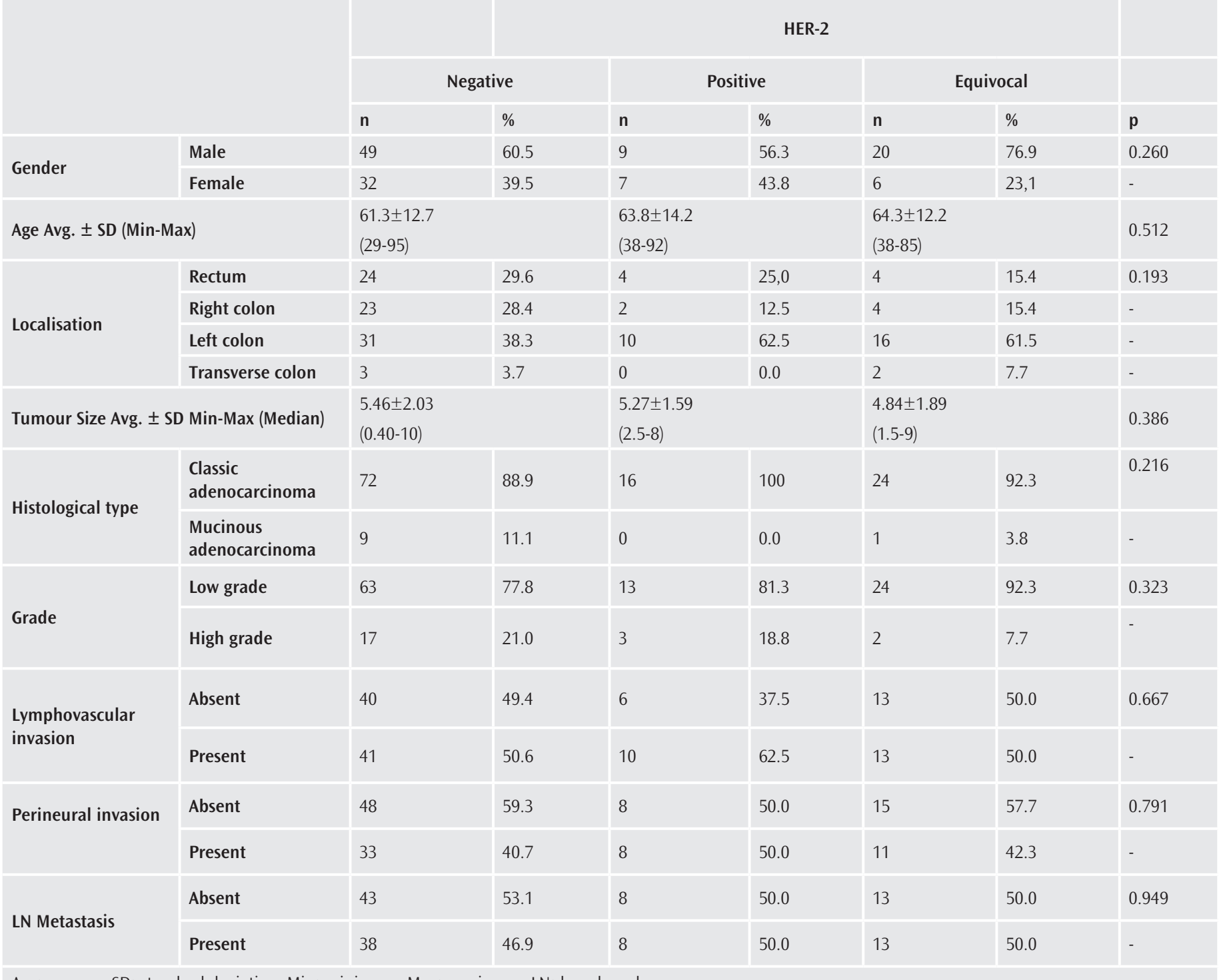

Avg: average, SD: standard deviation, Min: minimum, Max: maximum, LN: Iymph node 
Table 2. Distribution of HER-2 expression according to pTNM

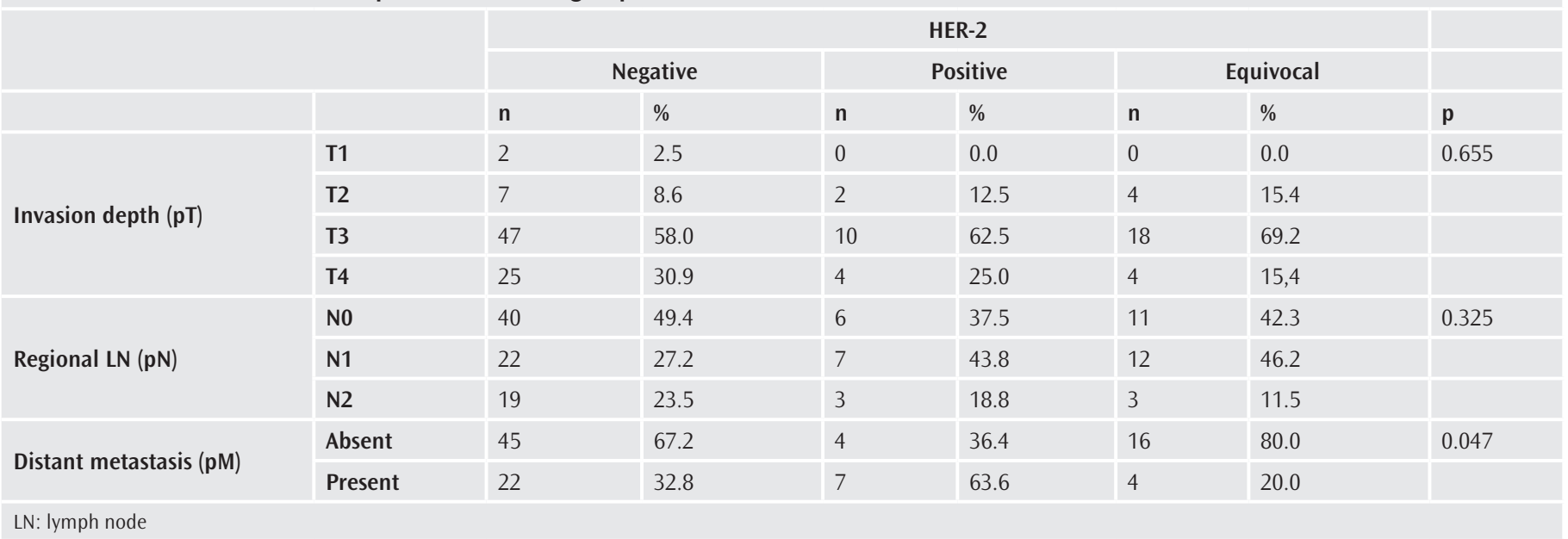

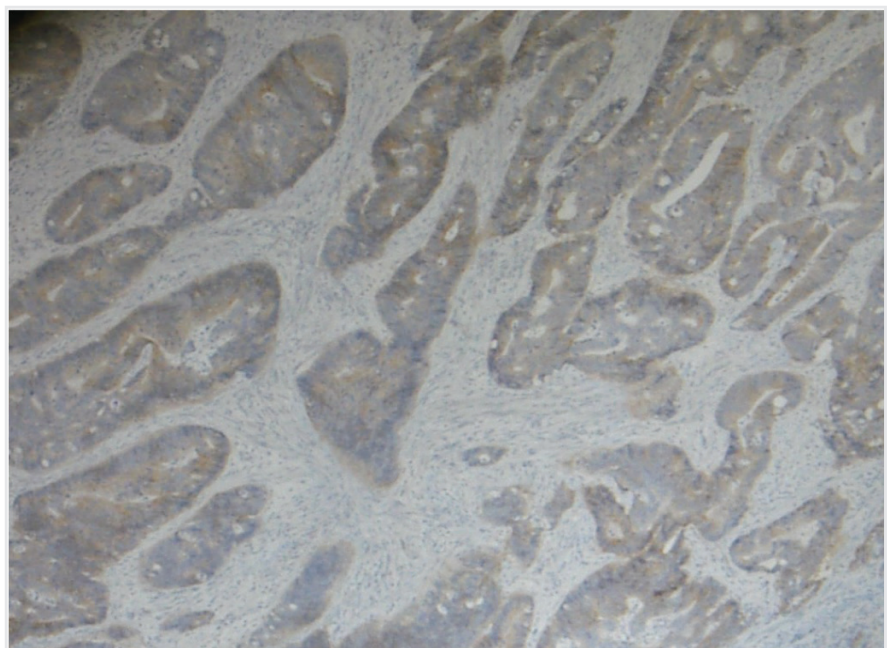

Figure 2. Tumour cells with Her-2 score 1+ (100x)

we showed that there was a significant relationship between HER-2 and distant metastasis.

We found no relation between Her-2 score and other parameters such as lymphocytes infiltrating the tumour $(p=0.310)$, Crohn-like response $(p=0.804)$, tumour nodules $(p=0.700)$, presence of a mucinous component $(p=0.110)$ and poorly differentiated area $(p=0.693)$.

Figure 2-4 shows positively stained samples with Her-2 scores 1+, 2+ and $3+$

\section{Discussion}

In our study, we examined the frequency of HER-2 expression in adenocarcinoma, which is a primary tumour of the colon and rectum, considering its potential role in the treatment of advanced disease, and compared its relationship with prognostic factors.

In recent years, studies investigating the frequency of HER-2 expression in CRCs and determining its relationship with various prognostic factors have been published. However, the results of these studies are not very compatible with each other. Various studies have reported HER-2

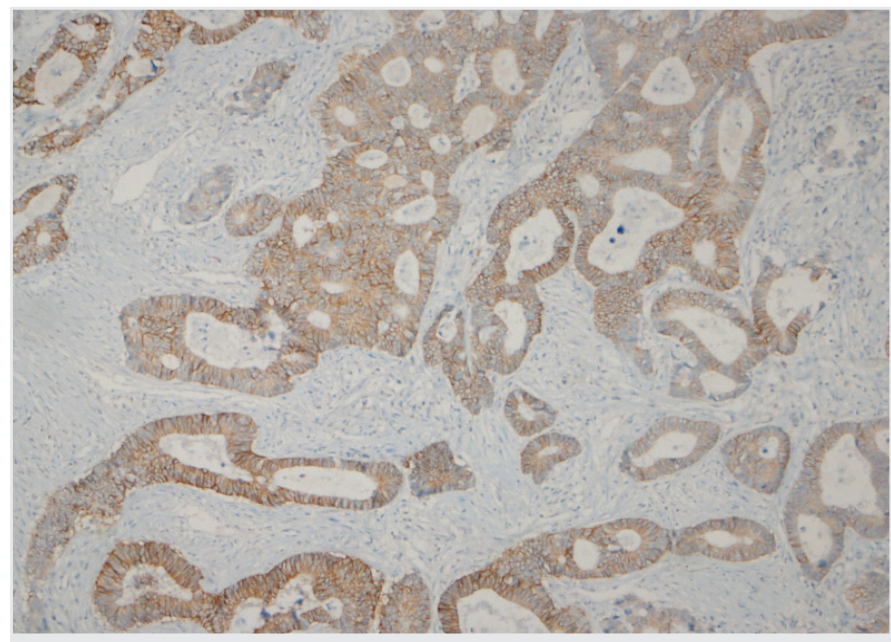

Figure 3. Tumour cells with Her-2 score 2+ (100x)

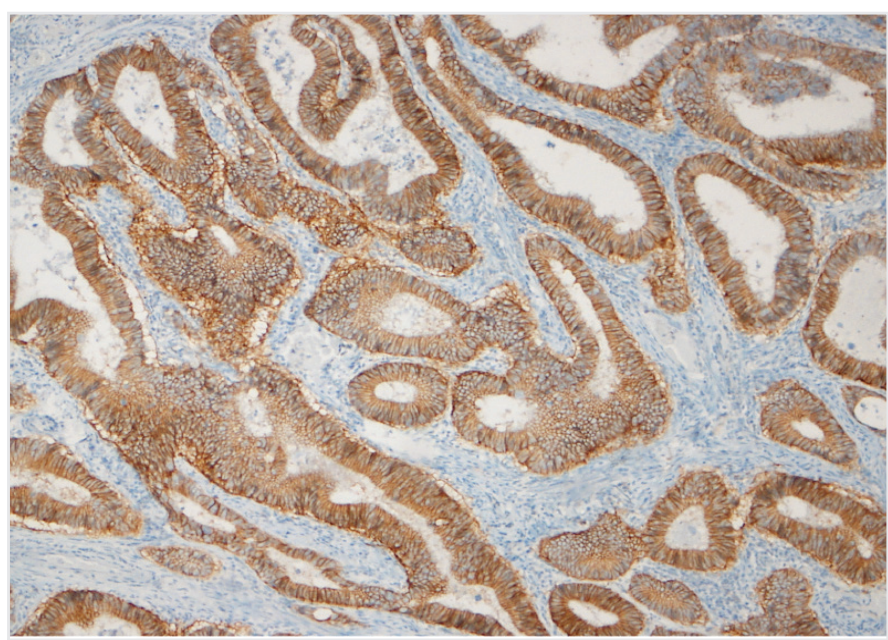

Figure 4. Tumour cells with Her-2 score 3+ (100x)

expression at rates ranging from 0 to $83 \%(8,13,14)$. In our study, strong membranous staining was observed in $13 \%$ of cases, but we detected immunoreactivity at varying concentrations in $50 \%$ of our cases. 
We showed that there is a significant relationship between HER-2 and distant metastasis. An analysis of studies investigating the relationship between HER-2 expression and stage found conflicting results. A number of studies $(7,14,15)$ reported that HER-2 was correlated with stage; others (10,16-18) found no relationship between the two. Yang et al. (14) found HER-2 expression to be associated with depth of invasion, Dukes stage, and lymph node metastasis, but not with TNM stage. Gill et al. (19) found a correlation between metastatic lymph node and HER-2 positivity. Like us, Li et al. (17) did not find any association with T-stage and lymph node metastasis but found a significant difference between HER-2 expression and distant metastasis $(p=0.010)$.

In contrast to our study, Demirbaş et al. (20) found that tumours located in the rectum show HER-2 expression more frequently. In contrast, Schuell et al. (13) reported a positive HER-2 frequency in tumours with a decreasing tendency from colon to rectum, and they did not find a statistically significant difference $(p=0.251)$. Other authors did not find a significant correlation between HER-2 and tumour localisation as in our study $(14,16,21)$.

In the same study by Demirbaş et al. (20) tumours were classified as larger than $5 \mathrm{~cm}$ or between $1.1-5 \mathrm{~cm}$ and $1 \mathrm{~cm}$, and a positive relationship was found between HER-2 expression and tumour size. Li et al. (17) classified tumours smaller and larger than $5 \mathrm{~cm}$ in their study and showed that tumour size correlated with HER-2 expression $(p=0.004)$. However, in the studies of Yang et al. (14), Albayrak et al. (16) and Torabizadeh et al. (18) and in the meta-analysis of Sun et al. (7), including 30 case-control studies, it was reported that HER 2 expression was not related to tumour size. We did not find a significant difference in our research.

There is a preponderance of original studies indicating that there is no relationship between HER-2 expression distribution and histological grade $(13,14,17,18,21)$. Wu et al. (10) included 18 studies and Sun et al. (7) included 30 studies in meta-analyses, and no relationship between histological grade and HER-2 expression was observed in either metaanalysis. In contrast, Albayrak et al. (16) reported a relationship between HER-2 expression and histological grade in their study including 15 high grade cases.

These differences between studies may have been caused by many factors. One of the most important is the variation in primary antibodies used in the studies. For example, Li et al. (17) used the hercep test kit, Gill et al. (19) used monoclonal RTU-CB11, Seo et al. (22) used monoclonal 4B5 antibody and many different types of primary antibodies were preferred in different studies. A second factor is the use of different scoring systems. To date, there is no HER-2 scoring system approved for CRC. Therefore, the cut-off values differ from one study to the next. For example, Üner et al. (23) accepted 20\% cell staining as the positive cut-off limit, while in many other studies $10 \%$ was considered as the limit. The evaluation of cytoplasmic staining in some studies can be considered as important reasons for the differences in the literature.

There are some limitations to our study. We performed immunohistochemical staining on the blocks that best represented the tumour. We observed that HER-2 showed heterogeneous staining in the same tumour. Although we could predict this in advance, we could not stain too many blocks of the same tumour due to some limitations. In addition, we do not know whether the fixation was performed correctly, since our cases were from past years.

\section{Conclusion}

As a result, we detected +3 in $13 \%,+2$ in $21 \%$ and +1 in $16 \%$ cases of HER2 immunoreactivity. Given these noteworthy HER-2 expression levels, HER-2 may play a role in the treatment of patients who are resistant to anti-EGFR therapy in the coming days. However, in order to determine which patients will be candidates for treatment, it is sufficient to look at HER-2 expression alone or to determine which concentrations of staining would be considered as significant; Studies supporting amplification of HER-2 expression should be increased, and a standard scoring system should be established to evaluate HER-2 expression in CRCS.

\section{Ethics}

Ethics Committee Approval: The study was approved by the ethics committee of Haseki Training and Research Hospital (428/22.02.2017).

Informed Consent: No consent was obtained from the patients.

Peer-review: Externally peer-reviewed.

Author Contributions: Concept - C.B.I., S.G.B.; Design - C.B.I.; Data Collection and/ or Processing - S.G.B., C.B.I.; Analysis and/or Interpretation - S.G.B., C.B.I.; Literature Search - C.B.I.; Writing - C.B.I.

Conflict of Interest: No conflict of interest was declared by the authors.

Financial Disclosure: This research was financially supported both via oral presentation and the thesis by the Haseki Training and Research Hospital Management Thesis and Academic Studies Advisory and Monitoring Commission.

\section{References}

1. https://gco.iarc.fr/today/online-analysis-table?v=2018\&mode $=$ cancer\&mode_population $=$ continents\&population $=900 \&$ populations $=$ $900 \&$ key $=$ asr $\&$ sex $=0 \&$ cancer $=39 \&$ type $=\quad 1 \&$ statistic $=5 \&$ prevalence $=$ $0 \&$ population_group $=0 \&$ ages_group $\% 5 \mathrm{~B} \% 5 \mathrm{D}=0 \&$ ages_group $\% 5 \mathrm{~B} \% 5 \mathrm{D}$ $=17 \& n b \_$items $=5 \&$ group_cancer $=1 \&$ include_nmsc $=1 \&$ include_nmsc other $=1$

2. Nam SK, Yun S, Koh J, Kwak Y, Seo AN, Park KU, et al. BRAF, PIK3CA, and HER2 oncogenic alterations according to KRAS mutation status in advanced colorectal cancers with distant metastasis. PLoS One. 2016;11:e0151865.

3. Walther A, Johnstone E, Swanton C, Midgley R, Tomlinsonn I, Kerr D. Genetic prognostic and predictive markers in colorectal cancer. Nat Rev Cancer 2009;9:489-99.

4. Martin V, Landi L, Molinari F, Fountzilas G, Geva R, Riva A, et al. HER2 gene copy number status may influence clincal efficacy to anti-EGFR monoclonal antibodies in metastatic colorectal cancer patients. Br J Cancer 2013;108:66875 .

5. Leto SM, Trusolino L. Primary and acquired resistance to EGFR-targeted therapies in colorectal cancer: impact on future treatment strategies. J Mol Med (Berl) 2014; 92:709-22

6. Shabbir A, Mirza T, Khalid AB, Qureshi MA, Asim SA. Frequency of Her2/neu expression in colorectal adenocarcinoma: a study from developing South Asian Country. BMC Cancer 2016;16:855.

7. Sun SJ, Lin Q, Sun Q, Li J, Zhang XY, Tan ZG, et al. High HER-2 protein levels correlate with clinicopathological features in colorectal cancer. Journal of cancer research and therapeutics 2016;12:323-33. 
8. Farzand S, Siddique T, Saba K, Bukhari MH. Frequency of HER2/neu overexpression in adenocarcinoma of the gastrointestinal system. World J Gastroenterol 2014;20:5889-96.

9. Madani SH, Sadeghi E, Rezaee A, Sadeghi M, Khazaee S, Amirifard N, et al. Survey of HER2-neu Expression in Colonic Adenocarcinoma in the West of Iran. Asian Pac J Cancer Prev 2015;16:7671-4.

10. Wu SW, Ma CC, Li WH. Does overexpression of HER-2 correlate with clinicopathological characteristics and prognosis in colorectal cancer? Evidence from a meta-analysis. Diagn Pathol 2015;10:144.

11. Ung L, Chua TC, Merrett ND. Targeting HER2 amplifications in gastric cancer. Gastrointestinal Cancer: Targets and Therapy 2014;4:11-22.

12. Richman SD, Southward K, Chambers P, Cross D, Barrett J, Hemmings G, et al. HER2 overexpression and amplification as a potential therapeutic target in colorectal cancer: analysis of 3256 patients enrolled in the QUASAR, FOCUS and PICCOLO colorectal cancer trials. J Pathol 2016;238:562-70.

13. Schuell B, Gruenberger T, Scheithauer W, Zielinski C, Wrba F. HER 2/neu protein expression in colorectal cancer. BMC Cancer 2006;6:123.

14. Yang WJ, Shen XJ, Ma XX, Tan ZG, Song Y, Guo YT, et al. Correlation of human Epidermal growth factor receptor protein expression and colorectal cancer. World J Gastroenterol 2015;21:8687-96.

15. Kapitanovic S, Radosevic S, Kapitanovic M, Andelinovic S, Ferencic Z, Tavassoli M, et al. The expression of $\mathrm{p} 185$ (HER-2/neu) correlates with the stage of disease and survival in colorectal cancer. Gastroenterology 1997;112:1103-13.
16. Albayrak A, Gürsan N, Gündoğdu C. Kolorektal kanserlerde c-erbB-2 ve p53 ekspresyonunun prognostik önemi. Journal of Clinical and Experimental Investigations 2014;5:80-5.

17. Li Q, Wang D, Li J, Chen P. Clinicopathological and prognostic significance of HER 2/neu and VEGF expression in colon carcinomas. BMC Cancer 2011;11:277-82.

18. Torabizadeh Z, Nosrati A, Tahvildari S. Human Epidermal growth factor receptor expression in colorectal cancer and its relationship with clinicopathlogical characteristics. Middle East Journal of Digestive Diseases 2016;8:24-30.

19. Gill MK, Manjari M, Jain K, Kaur T. Expression of Her-2/neu in colon carcinoma and its correlation with the histological grades and the lymph node status. J Clin Diag Res 2011;5:1564-8.

20. Demirbaș S, Sücüllü I, Yıldırım \$, Çelenk T. Influence of the c-erb B-2, nm23, bcl-2 and p53 protein markers on colorectal cancer. Turk J Gastroenterol 2006;17:13-9.

21. Jesus EC, Matos D, Artigiani R, Waitzberg AFL, Goldenverg A, Saad SS. Assessment of staging, prognosis and mortality of colorectal cancer by tumor markers: receptor erbB-2 and cadherins. Acta Cirurgica Brasileira 2005;20:422-7.

22. Seo AN, Kwak Y, Kim DW, Kang SB, Choe G, Kim WH, et al. HER2 status in colorectal cancer: its clinical significance and the relationship between HER2 gene amplification and expression. Plos One 2014;9:e98528.

23. Üner A, Ebinc FA, Akyürek N, Ünsal D, Menteș BB, Dursun A. Vascular endothelial growth factor, C ERB-2 and C-ERBB-3 expression in colorectal adenoma and adenocarcinoma. Exp Oncol 2005;27:225-8. 